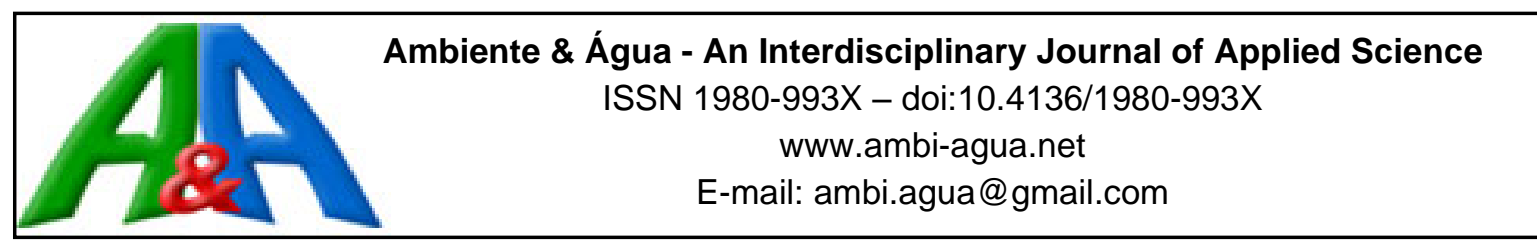

\title{
Hazard assessment and categorization of microbiological risk in a water treatment and distribution system located in a municipality in the interior of Minas Gerais, Brazil
}

\author{
ARTICLES doi:10.4136/ambi-agua.2450
}

Received: 08 Aug. 2019; Accepted: 01 Apr. 2020

\begin{abstract}
Marcelo Barbosa Motta ${ }^{1 *(i D} ;$ Elisabeth Neumann ${ }^{2}$ (iD
${ }^{1}$ Gerência Regional de Saúde de Itabira. Secretaria de Estado de Saúde de Minas Gerais (SES), Avenida Vila Lobos, $n^{\circ}$ 121, CEP: 35900-557, Itabira, MG, Brazil.

${ }^{2}$ Instituto de Ciências Biológicas. Departamento de Microbiologia. Universidade Federal de Minas Gerais (UFMG), Avenida Presidente Antônio Carlos, nº 6627, CEP: 31270-901, Belo Horizonte, MG, Brazil. E-mail: eneumann@icb.ufmg.br

*Corresponding author. E-mail: marcelobarbosamotta@gmail.com
\end{abstract}

\begin{abstract}
Consumption of non-potable water is a relevant public health problem due to the possibility of transporting numerous chemical and microbiological contaminants. In 2005, the Brazilian Ministry of Health created the National Program of Surveillance in Environmental Health related to the Quality of Water for Human Consumption (VIGIAGUA), with the primary purpose of managing risks related to water supply to human populations in Brazilian territory. However, VIGIAGUA does not have a methodology capable of characterizing or managing risks. The objective of this research is to create a working model to transform raw data into conceptual data related to low-, medium- and high-risk levels. The data used in the application of the model were obtained through the analyses of water-quality surveillance conducted by the Regional Health Management of Itabira, a municipality with less than 10 thousand inhabitants, whose history of water contamination is alarming. Twelve samples/month were collected between May 2017 and April 2018. The results of the treated water analyses were classified according to the presence of hazards and categorized into risk levels. The results showed $83.3 \%$ contamination by total coliforms at the treatment plant and $91.6 \%$ in the distribution system. The Escherichia coli contamination was $16.7 \%$ in the treatment plant samples and $45.2 \%$ in the distribution system. The system was categorized as "High Risk". The analysis of untreated water samples was carried out for the purpose of knowing the contamination pattern of the raw water of the region, finding $100 \%$ contamination by total coliforms and $97.2 \%$ contamination by E. coli.
\end{abstract}

Keywords: surveillance health, water analysis, water quality.

\section{Avaliação de perigos e categorização do grau de risco microbiológico em um sistema de tratamento e distribuição de água localizado em um município do interior de Minas Gerais, Brasil}

\section{RESUMO}

O consumo de água não potável é um relevante problema de saúde pública devido à possibilidade de veiculação de inúmeros contaminantes químicos e microbiológicos. Em 2005, 
o Ministério da Saúde Brasileiro criou o Programa Nacional de Vigilância da Qualidade da Água para Consumo Humano (VIGIAGUA), com a finalidade primordial de gerenciar riscos relacionados ao fornecimento de água a populações humanas no território brasileiro. Entretanto, o VIGIAGUA não possui uma metodologia capaz de caracterizar ou gerenciar riscos. $\mathrm{O}$ objetivo desta pesquisa é criar um modelo de trabalho para transformar dados brutos em dados conceituais relacionados aos níveis de risco classificados em baixo, médio e alto. Os dados utilizados na aplicação do modelo foram obtidos de um município com menos de 10 mil habitantes, adscrito à gerência Regional de Saúde de Itabira, cujo histórico de contaminação da água é alarmante. Foram coletadas 12 amostras/mês entre maio de 2017 e abril de 2018. Os resultados das análises de água tratada foram classificados segundo a presença de perigos e categorizados em níveis de risco. Os resultados apresentaram 83,3\% de contaminação por coliformes totais na saída do tratamento e $91,6 \%$ na rede de distribuição. A contaminação por Escherichia coli foi de 16,7\% nas amostras da saída do tratamento e 45,2\% na rede de distribuição. O sistema foi categorizado em "Alto Risco". A análise de amostras de água não tratada foi realizada com a finalidade de conhecer o padrão de contaminação da água bruta da região, resultando em $100 \%$ de contaminação por coliformes totais e 97,2\% de contaminação por E. coli.

Palavras-chave: análise da água, qualidade da água, vigilância em saúde.

\section{INTRODUCTION}

Water is an essential resource for human life and its availability on land is increasingly scarce. Of the water resources available on the planet, only $3 \%$ are fresh water, and of these, only $0.01 \%$ can be used for human consumption, after adequate treatment. This little availability of water is constantly threatened by human action, mainly through runoff resulting from agricultural and industrial activities, which can lead to contamination of groundwater by heavy metals. In addition to chemical contamination, the microbiological quality of the water must be suitable for human consumption (Saleh et al., 2018).

Global potable water guidelines recommend that faecal indicator bacteria, preferably Escherichia coli, should not be detectable in any $100 \mathrm{~mL}$ sample aliquot. However, worldwide water quality reports describe faecal contamination in water sources for human consumption, especially in low-income countries, where supply systems are not sufficient to contain the viability of microorganisms in water, favoring the occurrence of diarrheal diseases (Bain et al., 2014).

In the Brazilian scenario, the rate of diarrhea among children under five years has declined in the last decades, from 1,346,506 records in 1998 to 511,893 in 2015, attributed to better vaccine coverage and optimization of water resources management (Oliveira et al., 2017).

The relevance of efficient water resource management and potable water supply in the global burden of disease was recognized by the World Health Organization in 2013 through goal 7c of the Millennium Development Goals. This goal determined that by 2015 the proportion of the world's population without sustainable access to potable water needed to be reduced to $50.0 \%$ (Gnetry-Shields and Bartram 2014).

In Brazil, monitoring of the quality of water distributed to the population is attributed to the Unified Health System (SUS), carried out through the National Program for Monitoring Water Quality for Human Consumption - VIGIAGUA (Brasil, 2005), with the decentralization of actions to the State and Municipal Health Secretariats. In the State of Minas Gerais, the Program is executed by the State Secretariat of Health and Regional Health Units (URS) and in the municipalities, by the Municipal Health Secretariats.

The program aims to carry out risk analysis associated with the consumption of 
contaminated water, by monitoring the basic parameters related to the presence of total coliforms/E. coli, turbidity index and residual chlorine. However, it does not have methodology to characterize the risks in the work routine of health surveillance.

For the reasons presented and with the perspective of contributing to overcome the challenges of VIGIAGUA and improve the Program, this paper proposes a hazard assessment and categorization of microbiological risks associated with a water supply system, located in a mining municipality with less than 10.000 inhabitants, assigned to the Regional Health Management of Itabira (an agency linked to the State Health Department of Minas Gerais, Brazil), using the model suggested by Carmo et al. (2008).

\section{MATERIALS AND METHODS}

The methodologies used in this work are described in the American Water Works Association (AWWA) and Water Environment Federation (WEF), American Public Health Association (APHA), the American Water Works Association (AWWA) and the Standard Methods for the Examination of Water and Wastewater, as determined in Article 22 of Ordinance/MS 2.914/2011 (Brasil, 2011).

The Brazilian municipalities must comply with a minimum sampling plan for the evaluation of parameters of turbidity, free residual chlorine, total coliforms and E. coli, considered basic indicators of the microbiological quality of water for human consumption. The municipality object of this study has a population between 5,001 and 10,000 inhabitants, so according to VIGIAGUA guidelines, nine monthly samples were analyzed. Priority areas for sample collection were selected according to the points that historically presented the highest frequency of contamination and in accordance with the guidelines of the Brazilian Ministry of Health, prioritizing public areas with large circulation of people (health units, schools, hospitals, etc.) (Brasil, 2016). Two fixed points were defined at the exit of treatment for each of the two existing water treatment systems. Another 14 variable points were sampled alternately each month. Therefore, in the urban area, 9 samples/month were collected, 2 fixed points (treatment plants) and 7 at variable points, alternating between even and odd months. In addition, three additional collections were carried out in a locality considered to be an isolated urban area, whose water supply does not receive any type of treatment, and is only collected, stored and distributed. For these samples, the parameters of turbidity, total coliforms and E. coli were evaluated. The collections were carried out between the months of May/2017 and April/2018.

The technique of collecting and transporting the samples followed the "Item 5.4.4" of the Ezequiel Dias Foundation's Collection Manual (FUNED), under the register "NUMBER: DIOM-DIVISASGA-MQ 0001. Samples for analysis of total coliforms and E. coli were collected in sterile plastic bags containing sodium thiosulfate tablets for neutralization of chlorine. After collection, the pockets were packed in thermal boxes cooled with recyclable ice, kept at a temperature between $2^{\circ} \mathrm{C}$ to $8^{\circ} \mathrm{C}$ and transported to the GRS-Itabira laboratory within 22 hours.

The methodology for the identification of total coliforms and E. coli was based on the chromogenic substrate. The technique uses the hydrolyzable substrates ortho-nitrophenyl- $\beta$-Dgalactopyranoside (ONPG) and 4-umbelliferyl- $\beta$-D-glucuronide (MUG) for simultaneous detection of total coliforms ( $\beta$-D-galactosidase) and E. coli ( $\beta$-glucuronidase), identifying the bacteria through the yellow coloration resulting from ONPG hydrolysis, and fluorescence resulting from the hydrolysis of MUG seen under long wavelength UltraViolet light $(365 \mathrm{~nm})$, (APHA et al., 2012).

The method used to determine free residual chlorine (CRL) is based on the oxidation of $\mathrm{N}$, $\mathrm{N}$-diethyl- $p$-phenylenediamine (DPD) by chlorine, resulting in a rosy solution with intensity proportional to the concentration of free chlorine Soares et al. (2016). To measure the concentration of $\mathrm{CRL}$, a Policontrol ${ }^{\circledR}$ digital colorimeter was used, the procedures are 
described in the manufacturer's manual.

The turbidimetric analyses were performed using the Policontrol ${ }^{\circledR}$ digital Turbidimeter, respecting the procedures described in the manufacturer's manual.

Hazard assessment and categorization of the degree of risk was performed as suggested by Carmo et al. (2008) and described in the conclusion item (Table 1).

Table 1. Frequency of contamination by total coliforms in treated water samples in the priority collection areas between May/2017 and April/ 2018 of the Municipality studied-MG.

\begin{tabular}{lccc}
\hline Priority areas & N & n & $\mathrm{BI}_{\mathrm{TC}} \%$ \\
\hline School - 2 & 6 & 6 & 100.0 \\
Department of Public Administration - 1 & 6 & 6 & 100.0 \\
Department of Public Administration - 3 & 6 & 6 & 100.0 \\
Health Center - 1 & 6 & 6 & 100.0 \\
School - 4 & 6 & 6 & 100.0 \\
Department of Public Administration - 4 & 6 & 6 & 100.0 \\
Health Center - 2 & 6 & 6 & 100.0 \\
TS - 1 Treatment station & 12 & 10 & 83.3 \\
TS - 2 Treatment station & 12 & 10 & 83.3 \\
School - 1 & 6 & 5 & 83.3 \\
Department of Public Administration - 2 & 6 & 5 & 83.3 \\
CRSA & 6 & 5 & 83.3 \\
School - 3 & 6 & 5 & 83.3 \\
Department of Public Administration - 5 & 6 & 5 & 83.3 \\
Department of Public Administration - 6 & 6 & 5 & 83.3 \\
Hotel & 6 & 5 & 83.3 \\
Total samples collected x positive & $\mathbf{1 0 8}$ & $\mathbf{9 7}$ & $\mathbf{8 9 . 8}$ \\
Average & $\mathbf{6 . 7}$ & $\mathbf{6 . 0}$ & \\
Standard deviation & $\mathbf{2 . 0}$ & $\mathbf{1 . 6}$ & \\
\hline
\end{tabular}

$\mathrm{N}$ - number of samples collected.

$\mathrm{n}$ - number of samples with total coliforms.

$\mathrm{BI}_{\mathrm{TC}} \%$ - Bacteriological index of contamination by total coliforms.

The collected data were evaluated according to collection indicators (CI), related to the minimum sampling plan for the three basic parameters, bacteriological index (BI) (total coliforms and E. coli), turbidity index (TI) and index of free residual chlorine (IFRC) according to the formulas below:

CI $(\%)$

$=\frac{\text { Number of samples collected in various parts of the supply system }}{\text { Number of samples to be collected according to the sampling plan of the National Directive of VIGIAGUA }} \times 100$

$B I(\%)=\frac{\text { Number of samples with total coliforms or } E . \text { coli }}{\text { Number of samples collected }} \times 100$

$T I(\%)=\frac{\text { Number of samples that meet the turbidity standard }}{\text { Number of samples collected }} \times 100$

$I F R C(\%)=\frac{\text { Number of samples meeting the free residual chlorine standard }}{\text { Number of samples collected }} \times 100$

Pearson's chi-square test ( $p$ Value 0.05) was used to evaluate statistical significance in the dry and rainy periods in relation to the presence of $E$. coli and total coliforms in samples collected in the distribution system of the urban area (treated water) and treatment plants.

The Wilcoxon-Mann-Whitney test was applied to evaluate the statistical significance ( $p$ Value 0.05 ) between the values of the median turbidity results in the distribution system of 
the urban area (treated water) during the rainy and dry periods. In the treatment plants, the test was applied comparing the whole period of analysis and during the rainy and dry periods.

\section{RESULTS AND DISCUSSION}

Twelve monthly samples were collected between May 2017 and April 2018, totaling 144 samples, divided into 108 treated and 36 untreated. Among the $108(\mathrm{~N})$ treated water samples, $89.8 \%(\mathrm{n}=97)$ were positive for total coliforms and $38.9 \%(\mathrm{n}=42)$ for $E$. coli, (Tables 1 and 2). All samples showed non-compliance for the IFRC parameter (values $<0.2 \mathrm{mg} / \mathrm{L}$ recommended value: $0.2-2.0 \mathrm{mg} / \mathrm{L}$ ) and turbidity compliance except School 1, Department Public Administration 1 and (5 turbidimetric units - Tu) as a function of the sample standard deviation (Table 3). The microbiological standard determined by Administrative Rule no. 2,914/2011 is the absence of total coliforms in $100 \mathrm{~mL}$ of sample at the exit of the treatment, and in the distribution system (for systems that supply less than 20,000 inhabitants), tolerance of presence of coliforms in a sample/month. For presence of $E$. coli there is no tolerance in the exit and system or distribution. In addition to contamination reaching all sampled collection points, the most alarming result is the contamination ratio between the treatment outflows and the distribution system. For total coliforms, there was $83.3 \%$ contamination of the samples at the treatment exit, for the two treatment stations (TS-1 and TS-2) and $91.6 \%$ in the distribution system (Table 1). For E. coli, there was a $16.7 \%$ contamination of the samples at the treatment exit, for the two stations (TS-1 and TS-2), and 45.2\% in the distribution system (Table 2).

Table 2. Frequency of contamination by $E$. coli in samples of treated water in the priority collection areas between May 2017 and April 2018 of the Municipality studied - MG.

\begin{tabular}{lccc}
\hline Priority areas & N & n & BI $_{\mathrm{Ec}} \%$ \\
\hline School - 2 & 6 & 6 & 100.0 \\
Health Center - 1 & 6 & 5 & 83.3 \\
Health Center - 2 & 6 & 5 & 83.3 \\
Department of Public Administration - 2 & 6 & 4 & 66.7 \\
CRSA & 6 & 4 & 66.7 \\
Department of Public Administration - 3 & 6 & 3 & 50.0 \\
Department of Public Administration - 4 & 6 & 3 & 50.0 \\
School - 1 & 6 & 2 & 33.3 \\
TS - 1 Treatment station & 12 & 2 & 16.7 \\
TS - 2 Treatment station & 12 & 2 & 16.7 \\
Department of Public Administration - 1 & 6 & 1 & 16.7 \\
School - 3 & 6 & 1 & 16.7 \\
School - 4 & 6 & 1 & 16.7 \\
Department of Public Administration - 5 & 6 & 1 & 16.7 \\
Department of Public Administration - 6 & 6 & 1 & 16.7 \\
Hotel & 6 & 1 & 16.7 \\
Total samples collected x positive & $\mathbf{1 0 8}$ & $\mathbf{4 2}$ & $\mathbf{3 8 . 9}$ \\
Average & $\mathbf{6 . 7}$ & $\mathbf{2 . 6}$ & \\
Standard deviation & $\mathbf{2 . 0}$ & $\mathbf{1 . 7}$ & \\
\hline
\end{tabular}

$\mathrm{N}$ - number of samples collected

n - number of samples with $E$. coli

$\mathrm{BI}_{\mathrm{Ec}} \%$ - Bacteriological index of contamination by E. coli

The presence of total coliforms and E. coli in the water supply and distribution system persisted throughout the study months, and from July 2017 total coliform contamination was present in all samples analyzed. For $E$. coli, the highest frequencies of contamination were observed during the rainy season, between November and March (Santos and Garcia, 2016), especially in November/2017, January and February 2018, where percentage of contamination 
were $55.5 \%, 100.0 \%$ and $88.9 \%$, respectively. The result is in agreement with the fact that there is a consensus that the worsening tendency of water quality in rainy periods is a consequence of the drag of organic matter and various particles, which protect the microorganisms from contact with chemical disinfectants, which favors its viability (Gleason and Fagliano, 2017). The increase in the presence of particulate matter in the rainy season was also observed in the turbidity results, whose average values, considering all collection points in the urban zone, were lower in the driest months of the year (May to October 2017 and April of 2018 - 7 months) when compared to the rainy season months (November 2017 to March 2018 - 5 months) (Figure 1).

Table 3. Mean and median values of turbidity in samples of treated water by priority collection areas between May/2017 and April/2018 of the Municipality studied - MG.

\begin{tabular}{lccc}
\hline Priority areas & N & $\overline{\mathbf{y}}$ & $\tilde{\mathbf{Y}}$ \\
\hline School - 1 & 6 & $2.77 \pm 4,74$ & 0.95 \\
Department of Public Administration - 1 & 6 & $2.20 \pm 3,26$ & 0.95 \\
Department of Public Administration - 3 & 6 & $1.22 \pm 1,19$ & 0.84 \\
Health Center - 1 & 6 & $1.05 \pm 0,96$ & 0.80 \\
CRSA & 6 & $1.05 \pm 1,49$ & 0.57 \\
TS - 2 Treatment station & 12 & $0,92 \pm 0,88$ & 0.79 \\
Department of Public Administration - 2 & 6 & $0,88 \pm 0,74$ & 0.79 \\
Department of Public Administration - 4 & 6 & $0,70 \pm 0,60$ & 0.46 \\
Hotel & 6 & $0,69 \pm 0,51$ & 0.60 \\
School - 3 & 6 & $0,67 \pm 0,62$ & 0.48 \\
Department of Public Administration - 6 & 6 & $0,65 \pm 0,46$ & 0.55 \\
School - 2 & 6 & $0,61 \pm 0,62$ & 0.49 \\
Health Center - 2 & 6 & $0,61 \pm 0,70$ & 0.34 \\
Department of Public Administration - 5 & 6 & $0,59 \pm 0,63$ & 0.35 \\
TS - 1 Treatment station & 12 & $0,56 \pm 0,65$ & 0.28 \\
School - 4 & 6 & $0,24 \pm 0,19$ & 0.26 \\
Total samples collected x positive & $\mathbf{1 0 8}$ & & \\
Average & $\mathbf{6 . 7}$ & & \\
Standard deviation & $\mathbf{2 . 0}$ & & \\
\hline
\end{tabular}

$\mathrm{N}$ - number of samples collected

$\overline{\mathrm{y}}$ - average value

$\tilde{Y}-$ median

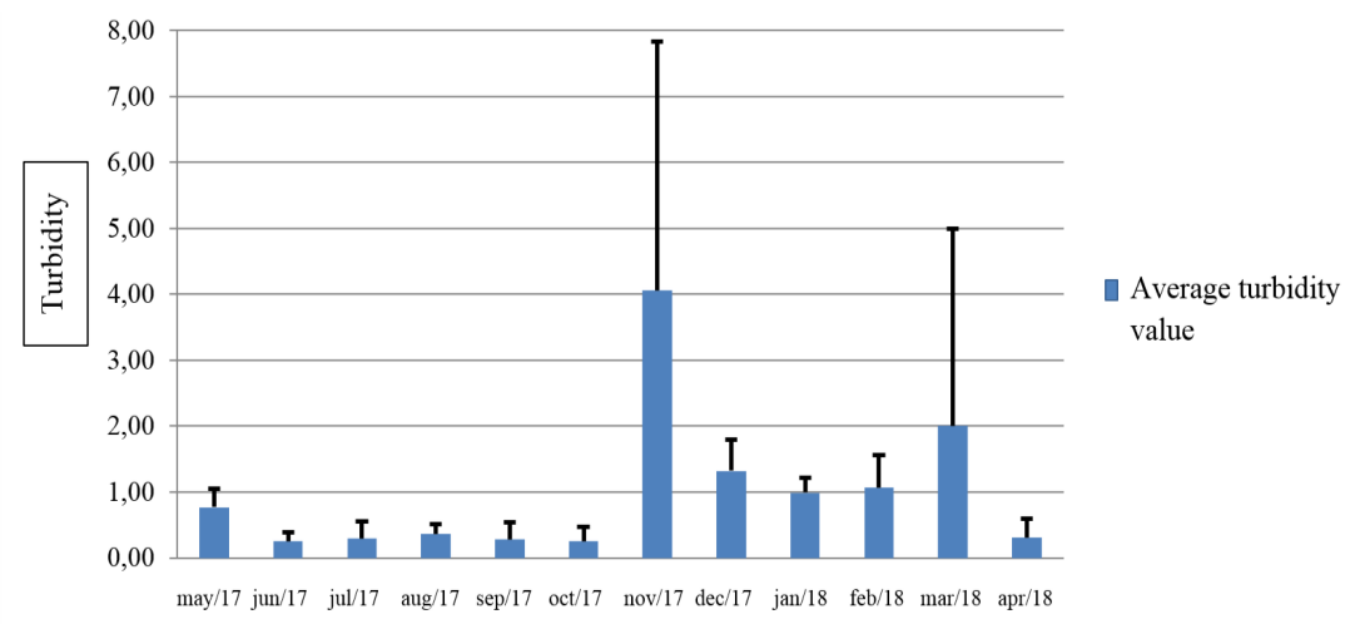

Figure 1. Average turbidity in the distribution system between May/2017 to April/2018 in the urban area of the studied municipality.

Microbiological results are a consequence of the inefficiency of chlorination, since 
chlorine concentrations below $1 \mathrm{mg} / \mathrm{L}$ favor the formation of biofilms (Liu et al., 2015). A similar result was demonstrated in the study by Yousefi et al. (2018), who identified an increase in the viability of total coliforms due to the decrease in the amount of free residual chlorine, in water for human consumption, in villages in the city of Poldasht, Iran.

In addition, the particulate material, transported through the distribution system as a result of non-existent or inadequate filtration processes, can deposit in the bottom of the tubes, and the inlaying of particles and materials with nutritive potential also favor the formation of biofilms, facilitating the viability and dissemination of potentially pathogenic agents (Liu et al., 2013).

Although Administrative Rule no. 2,914/2011 recommends that the $\mathrm{pH}$ of the water be maintained in the range of 6.0 to 9.5 in the distribution system, the ideal value for disinfection with chlorinated derivatives is 8.0 , because at this value there is an availability of hypochlorous acid around 35\%. When the $\mathrm{pH}$ assumes values of 8.5; 9.0 and 9.5; hypochlorous acid becomes available in the respective percentages of $12 \%, 5 \%$ and $2 \%$, which is insufficient for the disinfection process (Antonio and Macedo, 2004). During this study, three $\mathrm{pH}$ measurements were performed at a temperature of $26.9^{\circ} \mathrm{C}$. Two in samples from treatment station (TS-1), one before treatment and another post-treatment, and one sample in the distribution system (School 2 ), whose values were respectively $10.31 ; 9.10$ and 8.95 . These results demonstrate that even with the use of chlorinated disinfectants, if there is no adequate chemical correction of $\mathrm{pH}$ in the treatment plants, the microbiological protection will not be effective.

The structure and functioning of the treatment plants have direct relevance in the results found. The lack of complete cycle in the treatment (coagulation, flocculation, sedimentation and filtration), in the case of TS-1, which has only a chlorination process in the Parshall gutter, does not guarantee the final quality of the product. TS-2 has the physical structure to perform the complete treatment cycle, but does not use the chemicals necessary for the process, as well as to promote the dilution of the chlorinated water by TS-1, by opening the floodgates of its filters, transferring water without treatment for TS-1 reservoirs. The situation is aggravated by the meeting in the distribution system of the water coming from the two treatment plants, which makes it difficult to identify the origin and exact water flow.

When comparing the percentage of total coliforms and $E$. coli of all treated water samples collected in the urban area between the rainy and dry periods, these were significantly higher for the two parameters in the rainy season (Figures 2A and 2B). The same statistically significant difference occurred for the values of the turbidity medians between the two periods of the year, both for the samples collected from the distribution system (Figure 2C) and those collected at the exit of the treatment plants (Figure 2D). However, for the annual values of the turbidity medians between TS- 1 and TS-2, there is no statistical difference between them (Figure 2E), being considered an undesirable result due to oscillations in the rainy season. As the structural quality of the distribution system is fundamental for the production of drinking water, knowledge about the ecology of the bioindicator (E. coli) should be considered in the planning of actions to protect the source. This fact is important because it was initially believed that this bacterium inhabited exclusively the lower intestinal tract of warm-blooded animals at a concentration (per gram of feces) between $10^{7}-10^{9} \mathrm{CFU}$ in humans and $10^{4}-10^{6} \mathrm{CFU}$ in domestic animals. However, recent studies have shown that $E$. coli can survive for long periods of time in soil, sand, sediment and water, in tropical, subtropical and temperate climates, which facilitates its dissemination in water supply systems and explains the increased contamination during rainy periods (Jang et al., 2017). In addition, Frick et al. (2018) evaluated the abundance of E. coli in several groups of animals (homeothermic and poikilothermic), in an alluvial backwater in Austria, whose results showed the average concentrations of this bacterium in poikilothermic excreta, close to those found in homeothermic plants, confirming that its occurrence it is not exclusive to warm-blooded animals. 
The results show the inability of the municipal supply system to contain the presence of bacteria and other potentially pathogenic agents, such as viruses and protozoa, which constitute a microbiological hazard for the transmission of these microorganisms (Nabeela et al., 2014).

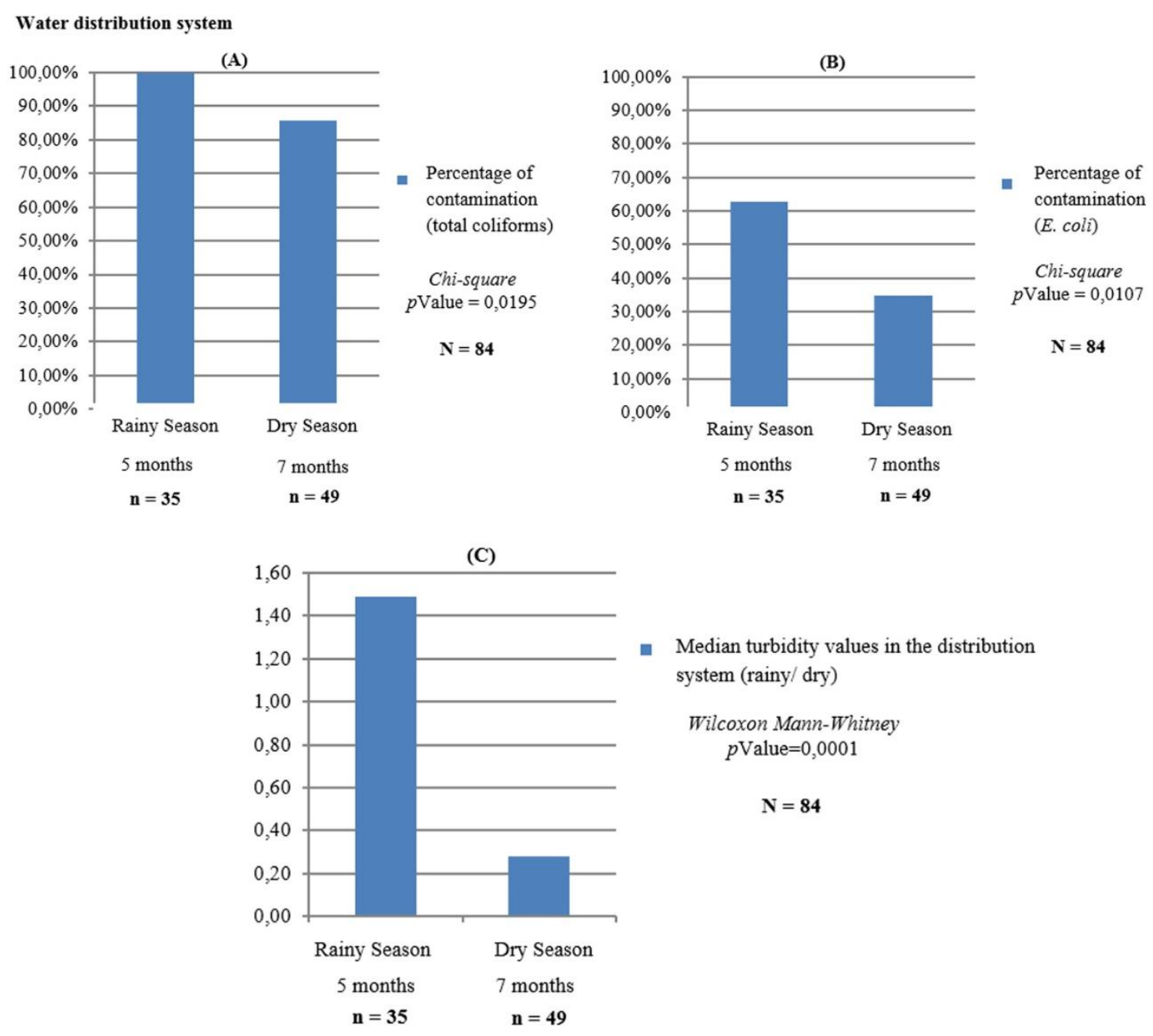

Water treatment plant
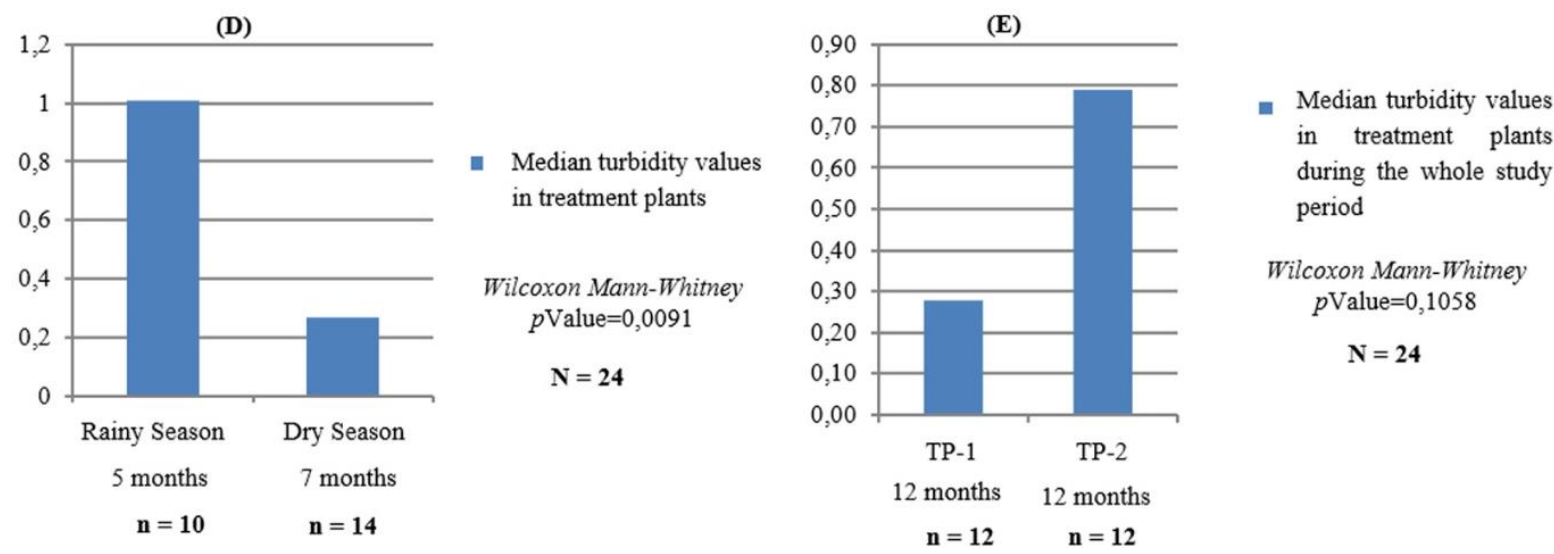

Figure 2. Percentage of total coliform contamination in the urban area in the rainy and dry seasons (A), percentage of E. coli contamination in the urban area in the rainy and dry seasons (B), median turbidity values in the urban area distribution system in the rainy and dry seasons $(C)$, median values of turbidity measured at plants TP-1 and TP-2 in the rainy and dry seasons (D), median turbidity values measured at plants TP-1 and TP-2 between May/2017 to April/2018 (E). 
Samples collected in the isolated urban area, where there is no water disinfection, presented $100 \%$ contamination by total coliforms and $97.2 \%$ E. coli contamination (Table 4). Regarding turbidity, among the 36 untreated water samples, $8.3 \%(n=3)$ presented unsatisfactory results. Two samples from the center of reference in social assistance (CRSA) - isolated urban area $(9,05 \mathrm{Tu}$ in Nov/2017 and 10,40 Tu in Apr/2018) and one from the Health Center - isolated urban area (7.69 Tu in nov/2017). The microbiological result of this area shows that the raw water quality (in nature) of the region represents a systematic danger, challenging and creating ever greater demands on the treatment system. Another important issue in relation to this area without water treatment refers to non-compliance with Article 24 of Administrative Rule no. 2,914/2011, which states that "All water for human consumption, supplied collectively, shall undergo disinfection or chlorination". Through the investigations carried out in loco, no communication was identified between the sources of abstraction and sanitary effluents that could contribute to the high index of contamination observed. According to information provided by the Municipal Environment Department, through the environmental engineer (technical manager), the municipal headquarters and the isolated urban area have adequate sewage treatment legislation. This information was verified by consulting the Brazilian Institute of Geography and Statistics website (https://ibge.gov.br/), whose registration confirms that the municipality has an adequacy of $88.6 \%$ of sewage.

Table 4. Frequency of contamination by E. coli, mean and median values of turbidity in samples of untreated water in the priority collection areas between May/2017 and April/2018 of the Municipality studied - MG.

\begin{tabular}{lccccc}
\hline Áreas prioritárias & $\mathbf{N}$ & $\mathbf{n E c}$ & $\mathrm{IB}_{\mathrm{Ec}} \%$ & $\overline{\mathbf{y}}$ & $\tilde{\mathbf{Y}}$ \\
\hline Health Unit - Isolated urban area & 12 & 12 & 100.0 & $1.56 \pm 2.09$ & 1.28 \\
School - Isolated urban area & 12 & 12 & 100.0 & $1.10 \pm 1.09$ & 0.53 \\
CRSA - Isolated urban area & 12 & 11 & 91.7 & $2.25 \pm 3.54$ & 0.86 \\
Total samples collected x positive & $\mathbf{3 6}$ & $\mathbf{3 5}$ & $\mathbf{9 7 . 2}$ & & \\
\hline
\end{tabular}

$\mathrm{N}$ - number of samples collected

nEC - number of samples with $E$. coli

$\mathrm{BI}_{\mathrm{Ec}} \%$ - Bacteriological index of contamination by E. coli

$\overline{\mathrm{Y}}$ - average value - turbidity

$\tilde{Y}$ - median - turbidity

Therefore, the high level of microbiological contamination present in the water of human consumption of this municipality can be directly associated with the absence of conventional treatment, inadequate structural flow of the treatment system, also considering the lack of use of chemical products like flocculants and $\mathrm{pH}$ correctors, besides the physical conditions of the pipes in the distribution, which do not have routine maintenance/prevention of corrosion or periodic replacement of old pipes, conditioning the formation of biofilms.

\section{CONCLUSION}

The results demonstrated the inability of the water treatment system analyzed to neutralize the presence of bacteria and other potentially pathogenic agents, like viruses and protozoa, which constitutes a microbiological hazard for their transmission. Therefore, the development of the methodology presented in this study is necessary to categorize the levels of risk associated with the hazard and to advise on the identification of flaws in the water treatment and distribution systems of this municipality, in order to promote corrective actions in water supply (Chart 1). The methodology used can be applied in the work routine of public health surveillance in other municipalities, as an instrument for monitoring water contamination for human consumption and allowing quick and adequate responses in the planning of governmental actions. 
Chart 1. Categorization of the risk associated to water consumption in the studied municipality, evaluated according to the presence or absence of hazards.

\begin{tabular}{lcc}
\hline \multicolumn{3}{c}{ Aspects related to the potability standard } \\
\hline Rated item & Treatment effect & Distribution system \\
\hline $\begin{array}{l}\text { Compliance with the minimum } \\
\text { sampling plan - total coliforms }\end{array}$ & Meets 100\% & Meets $100 \%$ \\
$\begin{array}{l}\text { Compliance with the minimum } \\
\text { sampling plan - free residual } \\
\text { chlorine }\end{array}$ & Meets 100\% & Meets 100\% \\
$\begin{array}{l}\text { Compliance with the minimum } \\
\text { sampling plan - turbidity }\end{array}$ & Meets 100\% & Meets $100 \%$ \\
$\begin{array}{l}\text { Evaluation of the bacteriological } \\
\text { quality of water: total coliforms }\end{array}$ & $83.3 \%$ & $91.6 \%$ \\
$\begin{array}{l}\text { Evaluation of bacteriological } \\
\text { quality of water: } E \text {. coli }\end{array}$ & Presence & Presence \\
$\begin{array}{l}\text { Evaluation of water quality: } \\
\text { turbidity }\end{array}$ & $16.7 \%$ & $45.2 \%$ \\
$\begin{array}{l}\text { Evaluation of water quality: free } \\
\text { residual chlorine }\end{array}$ & Presence & Presence \\
\hline
\end{tabular}

Aspects of a general nature - Statistical treatment

Statistically significant difference for the presence of total coliforms in the distribution system in treated water area during rainy/dry Unwanted outcome periods

Statistically significant difference for the presence of $E$. coli in the distribution system in

Unwanted outcome treated water area in the rainy/dry periods Statistically significant difference for turbidity in the distribution system in the area with treated water in the rainy/dry periods

Unwanted outcome

Statistically significant difference for turbidity between TS-1 and TS-2 in rainy/dry periods

Unwanted outcome

Statistically significant difference for turbidity between TS-1 and TS-2 (May/ 17 to Apr/18)

Unwanted outcome

High risk

\section{Subtitle:}

Low risk

Medium Risk

High risk
Attendance to all basic parameters of potability in the treatment exit and distribution system

Attendance to all the basic parameters of potability at the treatment exit, associated to the no attendance of the parameter for total coliforms in the distribution system.

Non-compliance with the defined parameter for $E$. coli. 


\section{REFERENCES}

ANTONIO, J.; MACEDO, J. A. B. O processo de desinfecção pelo uso de derivados clorados em função do pH e a Portaria 518/2004 do Ministério da Saúde. In: CONGRESSO BRASILEIRO DE QUÍMICA, 44., 2004, Fortaleza. Abstracts[...] Rio de Janeiro: ABQ, 2004.

APHA; AWWA; WEF. Standard Methods for the examination of water and wastewater. 22nd ed. Washington, 2012. 1496 p.

BRASIL. Ministério da Saúde. Diretriz nacional do plano de amostragem da vigilância da qualidade da água para consumo humano. Brasília, DF, 2016. 60 p.

BRASIL. Ministério da Saúde. Portaria n. 2.914, de 12 de dezembro de 2011. Dispõe sobre os procedimentos de controle e de vigilância da qualidade da água para consumo humano e seu padrão de potabilidade. Diário Oficial [da] União: seção 1, Brasília, DF, p. 39, 14 de dez. de 2011.

BRASIL. Ministério da Saúde. Programa nacional de vigilância em saúde ambiental relacionada à qualidade da água para consumo humano. Brasília, DF, 2005.

BAIN, R.; CRONK, R.; HOSSAIN, R.; BONJOUR, S.; ONDA, K.; WRIGHT, J.; YANG, H.; SLAYMAKER, T.; HUNTER, P.; PRÜSS, U. A.; BARTRAM, J. Global assessment of exposure to faecal contamination through drinking water based on a systematic review. Tropical Medicine \& International Health, v. 19, p. 917-927, 2014. https://doi.org/10.1111/tmi.12334

CARMO, R. F.; BEVILACQUA, P. D.; BASTOS, R. K. X. Vigilância da qualidade da água para consumo humano: abordagem qualitativa da identificação de perigos. Engenharia Sanitária e Ambiental, v. 4, p. 426-434, 2008. https://doi.org/10.1590/S141341522008000400011

FRICK, C.; VIERHEILIG, J.; LINKE, R.; SAVIO, D.; ZORNIG, H.; ANTENSTEINER, R.; BAUMGARTNER, C.; BUCHER, C.; BLASCHKE, A. P.; DERX, J.; KIRSCHNER, A. K. T.; RYZINSKA-PAIER, G.; MAYER, R.; SEIDL, D.; NADIOTIS-TSAKA, T.; SOMMER, R.; FARNLEITNER, A. H. Poikilothermic animals as a previously unrecognized source of fecal indicator bacteria in a backwater ecosystem of a large river. Applied and Environmental Microbiology, v. 84, p. 1-15, 2018. https://dx.doi.org/10.1128/AEM.00715-18

GENTRY-SHIELDS, J. G.; BARTRAM, J. Human health and the water environment: Using the DPSEEA framework to identify the driving forces of disease. Science of the Total $\begin{array}{lllll}\text { Environment, } & \text { v. } & 468-469, & \text { p. } & 306-314,\end{array}$ https://doi.org/10.1016/j.scitotenv.2013.08.052

GLEASON, J. A.; FAGLIANO, J. A. Effect of drinking water source on associations between gastrointestinal illness and heavy rainfall in New Jersey. PLoS One, v. 3, p. 1-13, 2017. https://dx.doi.org/10.1371\%2Fjournal.pone.0173794

JANG, J.; HUR, H. G.; SADOWSKY, M. J.; BYAPPANAHALLI, M. N.; YAN, T.; ISHII, S. Environmental Escherichia coli: ecology and public health Implications-a review. Journal of Applied Microbiology, v. 123, p. 570-581, 2017. https://doi.org/10.1111/jam.13468 
LIU, G.; VERBERK, J. Q.; VAN, D. J. C. Bacteriology of drinking water distribution systems: an integral and multidimensional review. Applied Microbiology and Biotechnology, v. 97, p. 9265-9276, 2013. https://doi.org/10.1007/s00253-013-5217-y

LIU, L.; LE, Y.; JIN, J.; ZHOU, Y.; CHEN, G. Chlorine stress mediates microbial surface attachment in drinking water systems. Applied Microbiology and Biotechnology, v. 6, p. 2861-2869, 2015. https://doi.org/10.1007/s00253-014-6166-9

NABEELA, F.; AZIZULLAH, A.; BIBI, R.; UZMA, S.; MURAD, W.; SHAKIR, S. K.; ULLAH, W.; QASIM, M.; HADER, D. P. Microbial contamination of drinking water in Pakistan - a review. Environmental Science Pollution Research, v. 21, p. 1392913942, 2014. https://doi.org/10.1007/s11356-014-3348-z

OLIVEIRA, B. S. B.; OLIVEIRA, R. K. L.; BEZERRA, J. C.; MELO, F. M. S.; MONTEIRO, F. P. M.; JOVENTINO, E. S. Condições sociais e condutas maternas na prevenção e manejo da diarreia infantil. Cogitare Enfermagem, v. 4, p. e50294, 2017.

SALEH, H. N.; PANAHANDE, M.; YOUSEFI, M.; ASGHARI, F. B.; CONTI, G. O.; TALAEE, E.; MOHAMMADI, A. A. Carcinogenic and Non-carcinogenic Risk Assessment of Heavy Metals in Groundwater Wells in Neyshabur Plain, Iran. Biological Trace Element Research, v. 1, p. 251-261, 2018. https://doi.org/10.1007/s12011-018$1516-6$

SANTOS, L. F.; GARCIA, S. R. Início e Fim da Estação Chuvosa no Estado de Minas Gerais: Comparação de Duas Metodologias Diferentes. Revista Brasileira de Meteorologia, v.1, p. 92-104, 2016.

SOARES, S. S.; ARRUDA, P. N.; LOBÓN, G. S.; SCALIZE, P. S. Avaliação de métodos para determinação de cloro residual livre em áreas de abastecimento público. Semina: Ciências Exatas e Tecnológicas, v.1, p. 119-130, 2016. http://dx.doi.org/10.5433/16790375.2016v37n1p119

YOUSEFI, M.; SALEH, H. N.; YASERI, M.; MAHVI, A. H.; SOLEIMANI, H.; SAEEDI, Z.; ZOHDI, S.; MOHAMMADI, A. A. Data on microbiological quality assessment of rural drinking water supplies in Poldasht county. Elsevier, v. 17, p. 763-769, 2018. https://doi.org/10.1016/j.dib.2018.02.003 